\title{
Entrevista com a professora Ana Clara Torres Ribeiro*
}

Geosul - Estamos com a Professora Ana Clara para uma entrevista. Antecipadamente agradecemos a sua disposição, e iniciamos perguntando onde nasceu, como foi a sua infância, os primeiros anos escolares.

Ana Clara - Claro, é um prazer estar aqui e poder de alguma maneira conversar. Eu comecei agora a fazer uma espécie de memorial, pois quem sabe, enfim, eu faça um concurso titular. Não sabia por onde começar; é muito complicado porque o indivíduo que pensa é o indivíduo mesmo, quer dizer, não é uma coisa só externa do mundo das ideias, mas tem a ver com a sua trajetória. A minha trajetória é curiosa vamos dizer, porque tenho uma trajetória social descendente, e as pessoas em geral costumam subir socialmente. No meu caso estou descendo e há bastante tempo, toda a família. Nasci em um berço rico e viemos perdendo rápido ao longo da trajetória familiar e depois individual também, mas basicamente é descendente. A experiência escolar reproduz isso de alguma forma: entrei cedo na escola primária, em um colégio muito bom, que é o colégio Mello e Souza, onde tinha os grandes nomes da matemática inclusive, muito bons, e minha mãe era uma pessoa premonitória, nunca teve preconceito com relação à orientação das filhas, que tiveram oportunidade de estudo. Isso já vinha desde meu avô maçom que não fazia diferença no que concerne progresso entre homens e mulheres; então eu digo que nunca sofri preconceitos por ser mulher e nem dificuldades desse

* Professora do Instituto de Pesquisa e Planejamento Urbano e Regional UFRJ. Entrevista realizada em Florianópolis por ocasião do V Seminário de Avaliação do Ensino e da Pesquisa em Estudos Urbanos e Regionais em novembro de 2010 e que contou com a participação dos professores Leila Christina Duarte Dias, Elson Manoel Pereira e Maria Dolores Buss. A edição final do texto é da professora Ester Limonad (a quem a Comissão Editorial agradece). Texto revisado e autorizado pela família da entrevistada.

Geosul, Florianópolis, v. 26, n. 52, p 197-218, jul./dez. 2011 
tipo. Entrei no Mello e Souza, comecei o primário com cinco anos, criancinha mesmo em relação ao resto da turma, que tinha dois anos a mais do que eu, e sou muito pequenininha também. Ao mesmo tempo eu estudava música desde os quatro anos de idade, piano; minha mãe é violinista e eu insisti muito que queria fazer piano, então eu aprendia piano, estudava música e dança e fazia essa escola, era toda uma equação muito, vamos dizer, esforçada porque tudo isso demandava disciplina e bastante força pra você agüentar. Quando chegou uma outra fase, eu estava com doze anos mais ou menos, no meio do ginásio, aquilo me exauriu de alguma forma porque era exigência demais e era muito difícil porque o piano era sério, não era a graciosidade da burguesia, vamos dizer assim , era uma coisa dura mesmo, eu estudava horas e horas de piano, pois não era uma coisa menor na minha vida. Então acabei o ginásio numa escola muito fraca, porque não agüentava mais segurar tudo ao mesmo tempo, e parei de estudar depois do ginásio. $\mathrm{Na}$ época o Conservatório Brasileiro de Música não demandava que você tivesse o que hoje é o segundo grau pra você se formar, então me graduei em musica, sem o clássico, sem o cientifico, eu nunca fiz clássico ou cientifico, nunca tive uma aula de física ou de química na minha vida, nada. Terminei o curso de música e já fazia composição, contraponto, harmonia, pra fazer a regência, eu fazia isso, e isso demandava muito, eu era muito nova, tinha uns dezesseis anos e as pessoas eram bem mais velhas. Acho que boa parte da minha cabeça vem da música, não vem da Universidade, ela vem da harmonia e da articulação mental matemática, ela vem da música, mas é matemática pura também, e física também. Nós tínhamos aula de ondas sonoras, de tudo que você pode imaginar da parte física da música, então isso tudo articula pra mim uma substituição. Nesta época perdi meu pai com dezesseis anos, uma coisa brutal. Tempo de crise psíquica da família, uma coisa muito complicada, e eu resolvi mudar de vida, não queria ficar mais só na música. Assim fiz o supletivo em Copacabana e fui colega, por exemplo, do assassino da "Aída Curi", caso famoso no Rio de Janeiro. Acho muita graça quando o 
pessoal me conta, os militantes que fizeram o Colégio de Aplicação. Eu tinha experiência completamente diferente; vivi coisas curiosas no meu supletivo, conheci pessoas do partido comunista dessa época, cheguei a conhecer o Arthur Moreira Lima e colegas tão loucos que juntava tudo, mas era uma turma muito incrível. Fiz as provas do supletivo, que na época era cerca de quarenta provas entre escritas e orais, porque eram feitas no Dom Pedro II, ou no colégio Nilo Peçanha, bastante forte, de Niterói. Na época, as faculdades federais ou nacionais não deixavam você fazer o vestibular sem o segundo grau completo, científico ou seja lá o que for, mas a $\mathrm{PUC}^{1}$ permitia. Então encontrei um amigo no ônibus, que era desses mais militantes, e ele disse: Ana Clara, por que você não vai fazer sociologia? Sem diploma mesmo, entra e você se articula. Eu não sabia o que era sociologia, mas fui fazer o vestibular de sociologia, e tinha muitas coisas que você estudava no ginásio mesmo, como história do Brasil. Eu passei e aquele mais militante não. Entrei sozinha na sociologia em 64 sem entender absolutamente nada dentro da política. Lembro que me chamaram no diretório acadêmico e me perguntaram assim: Ana Clara, o que você acha da $\mathrm{UNE}^{2}$ ? E eu digo: O que é que é isso? Estou disposta a aprender, mas eu não sei o que é a UNE. Então eu não sabia nem o que era a UNE. Eu era um ser estranhíssimo dentro da sociologia vindo da música, e as pessoas não queriam saber da minha formação musical para nada, e eu lá perdida dentro da sociologia assim, e para cúmulo da minha trajetória estranha, eu ainda fui trabalhar na rua Marquês de Olinda que foi a área mais reprimida da faculdade nacional, no Instituto de Ciências Sociais , eu fui lá trabalhar como bolsista de iniciação cientifica. Então eu conheci esse povo todo da Nacional $^{3}$ e da PUC que eram de diferentes tendências políticas. Fui aprendendo com muita

${ }^{1}$ Pontifícia Universidade Católica.

${ }^{2}$ União Nacional dos Estudantes.

${ }^{3}$ Faculdade Nacional de Filosofia da Universidade do Brasil. Com a reforma universitária iniciada em 1965, a Universidade do Brasil transformou-se um Universidade Federal do Rio de Janeiro (UFRJ). 
dificuldade, tentando entender o que era sociologia e ao mesmo tempo, vamos dizer, me posicionar numa conjuntura extremamente complicada que era essa de 64. Em 1968 terminei a graduação, em 69 mais ou menos fui integrada como auxiliar de ensino na UFRJ e em 72 eu pedi demissão da universidade. A repressão já era muito grande e terrível, as minhas experiências docentes foram muito duras porque eu dava aula para cento e vinte alunos com a polícia dentro da sala de aula. Dar sociologia nessas circunstancias era uma coisa terrível, tinha um risco muito alto, então pedi demissão da universidade em 72. Daí pronto, fui dar aula de tudo o que é coisa, de teatro, de cultura brasileira para poder viver.

Geosul - em 1972?

Ana Clara - A partir de 72. Fui fazer o curso de democracia, virei devota por certo tempo e fui me virando aprendendo muitas coisas, mas fora da estrutura regular. Mas isso pra mim nem era esquisito porque não era nada regular desde o início, então ficar irregular depois não chegava a ser impossível pra mim, eu continuava me virando, mas é uma trajetória bem fora do corrente vamos dizer assim, mesmo em termos escolares, eu não tive uma escolaridade formal, continuada, de jeito algum, então é estranho, e essa coisa do supletivo também no meio do caminho. Mas eu tive bons professores no supletivo, foi incrível também, eram pessoas que estavam com problemas de trabalho, militares perseguidos, bastantes situações, mas de alguma maneira gerava esse quadro docente que não era ruim o supletivo também, e até porque pra você passar no supletivo tinha que passar no Dom Pedro II, então não era exatamente assim tão desqualificado. Ao contrario, agora que a coisa é muito mais fluida, na época era muito duro pra você passar no supletivo, e aí essa experiência que tive bem maluca, mas que faz parte da minha trajetória...

Geosul - Ana Clara, nessa época que você estudou na PUC e trabalhou como bolsista em Botafogo na Marquês de Olinda, 
enfim, alguns professores que marcaram, que tiveram influência, um papel importante na tua formação? Quem seriam eles?

Ana Clara - São vários, tive excelentes professores na graduação de Sociologia e eu diria que além de excelentes professores o curso era muito bem estruturado. Acho que existem equívocos nas estruturas atuais do ensino da graduação que eu posso perceber por conta do contraste que foi aquele curso com poucas disciplinas, mas você lia muito e podia ler muito porque eram poucas as disciplinas, e tinha uma coisa muito bem pensada, porque você trabalhava a estrutura da sociedade e a transformação da sociedade, como é que isso acontecia acompanhado de indagações de metodologia e algumas disciplinas complementares da própria sociologia. Tinha aula de antropologia, de psicologia e de ciências políticas que são áreas complementares, mas ao mesmo tempo você tinha essa coluna dorsal muito forte que permitia que se fizessem grandes trabalhos, às vezes de vinte páginas para uma disciplina da graduação, quando hoje para pedir isso no mestrado parece que é pedir demais, ninguém agüenta. Os professores, muito marcantes, excelentes professores. Um deles era a coordenadora, que ficou muito próxima, quando sofri perdas de trabalho pela repressão mesmo, da ditadura, ela me apoiou bastante, e essa pessoa é a Helena Lewin, uma socióloga muito séria e muito equilibrada que hoje é Professora da UERJ ${ }^{4}$. Helena Lewin é pra mim uma pessoa absolutamente marcante, generosa, séria, solidária, excelente, dava aula de Teoria Sociológica logo no início e me ensinou sobre Octavio Ianni. Então quando foi o falecimento do Octavio Ianni eu escrevi um texto para um livro formalizado pelo Instituto Octavio Ianni que foi criado na UERJ. Teve um seminário e me chamaram, e eu recorri a um episódio formador proposto pela Helena Lewin na graduação, em que ela nos colocou para trabalhar como advogado de defesa e o seu colega era o advogado do diabo, o crítico, e eu fui a advogada de defesa de um livro do Ianni sobre o desenvolvimento econômico, desenvolvimento social, não me lembro o nome, acho que

${ }^{4}$ Universidade do Estado do Rio de Janeiro 
"Industrialização e Desenvolvimento Industrial". Desde então eu me tornei a advogada de defesa do Ianni, e vim trazendo essa marca, que ficou muito forte e que me encantou a vida inteira, a possibilidade de pensar o Brasil grandão assim como na cabeça do Ianni, pra mim foi uma maravilha. Outra figura muito importante é Miriam Limoeiro, que é da sociologia, trabalha com a questão da Teoria do Conhecimento, mas deu várias outras disciplinas para nós, e realmente em nossa turma a Miriam Limoeiro foi uma enorme professora, muito séria na questão da transformação do movimento, do que é criar uma categoria do pensamento, como é que isso se relaciona, a formação da episteme mesmo. Quando eu terminei a segunda disciplina, eu queria fazer um trabalho sobre o movimento e ela disse: Ana Clara, é um pouco cedo demais pra você, você é muito novinha, não pode ficar presa só ao trabalho de movimento. Então não deu pra fazer, mas nunca mais esqueci a coisa do movimento, que ficou atravessando a minha vida sempre. Tive professores belíssimos nas disciplinas complementares de apoio, na História o Manoel Maurício de Albuquerque, um dos maiores historiadores do Brasil, uma figura magnífica, que dava aula também de uma maneira inesquecível, porque ele juntava tempo e espaço; lembro do Manoel Maurício desenhando a cartografia, o mapa do Brasil de cabeça, no quadro negro, falando da sociedade nordestina, formação do Nordeste, desenhando, contando, relatando e transformando assim os nossos olhos. Então o Manoel Maurício e essa noção de tempo-espaço-historicidade, historicidade profunda, o elo da geografia com a história como sendo alguma coisa que não pode ser rompida, tudo isso é a formação .do Manoel Maurício. Tive um outro também na área de Direito e Sociologia que é o Evaristo de Moraes Filho, também uma figura muito reconhecida, um grande professor que nos ajudou muito a entender um pouco mais das instituições; ele trabalhava com as estruturas sociais, mas junto com as instituições e não como uma coisa sem instituições. Estava lendo agora uma entrevista com Francisco de Oliveira para o Centro Internacional Celso Furtado em que ele diz que é uma questão de dimensão institucional, se 
você quer qualquer tipo de justiça isso passa pela criação de instituições correspondentes e não por políticas circunstanciais, e isso era muito claro nos ensinamentos do Evaristo de Moraes, era claro na sua cabeça que deveria haver uma dimensão inclusive do estado de construção institucional de direitos. Tivemos também o Cândido Mendes, que apesar de, vamos dizer, não ser exatamente uma flor de simplicidade, porque as vezes você não conseguia compreender absolutamente nada do que ele dizia, mas mesmo assim, pela cultura que tinha, pelo conhecimento de mundo de centros internacionais, ajudava a abrir a cabeça para essa questão da escala internacional, como o mundo não se restringe ao Brasil, e isso o Cândido Mendes com certeza deixou marcas profundas em nossa formação. E tivemos muito outros bons, o Falcão também da História, ele dava história do Japão, falando da modernização, da modernidade. Então apesar de todas as dificuldades que nós vivíamos, porque era uma época política medonha, mesmo assim todos nós estudávamos, não havia essa de você se legitimar só como militante. Outra questão também que hoje falta é que os partidos, para você entrar, tinha que estudar muito a leitura de Marx, uma leitura direta de clássicos, então não é uma coisa que se faça no oba-oba; havia uma intenção de conhecimento, uma obrigação de conhecimento que era generalizada e não apenas na faculdade. As pessoas sentavam juntas pra estudar, estudar o Brasil, estudar o fascismo, estudar isso, aquilo, se estudava junto e isso é muito formador, no período da juventude é uma coisa que fica. Existia a influência mesmo da escola paulista da sociologia que na época era muito poderosa e de alguma maneira também nos ajudava com a vinda de muitos professores, inclusive o Fernando Henrique $^{5}$, que também é um grande sociólogo. Pode falar o que quiser do Fernando Henrique como presidente, mas como sociólogo ele realmente é um grande sociólogo.

5 Fernando Henrique Cardoso, sociólogo, que em 1995 assumiu a presidência do Brasil por duas gestões consecutivas (1995-1998 e 19992002) 
Geosul - E como é que se deu a sua passagem, do ponto de vista pessoal, da estudante de música, da estudante de supletivo que não sabia do que era a UNE para a socióloga?

Ana Clara - Por acaso é muito engraçado isso, só consigo atribuir eu ter virado socióloga, vamos dizer assim, pela minha mais estreita teimosia. Se há uma característica familiar marcante, é a teimosia, as mulheres da minha família são absolutamente teimosas, pode parecer assim boazinha e cordial, mas nós somos absolutamente teimosas e obsessivas. Então como na época, primeiro você tinha que terminar o que estava fazendo porque as alternativas não eram tão grandes assim, então se você tem uma chance qualquer você vai nela, porque pode ser que não apareça outra. Então isso era uma coisa importante, mas do outro lado é um princípio de teimosia relacionado à impossibilidade. A sociologia era muito reprimida e havia uma repressão contra o conhecimento da sociedade. Éramos muito reprimidos e isso de alguma maneira aumentou minha teimosia. Já que não pode ser, vai ser de qualquer forma, entendeu? É da minha natureza. Por isso que acho que eu fumo, quanto mais me reprimem mais eu fumo, porque é uma coisa que é da minha natureza, se ficarem insistindo muito eu vou fazer de qualquer forma, principalmente com essa coisa da repressão. $\mathrm{O}$ outro lado é a estrutura lógica, me encanta pensar totalidades complexas, isso por causa da música também, me encanta essa coisa de você pensar complexidades que tenham totalidades e como é que essas coisas se articulam, isso pra mim é encantador. Sofri uma espécie de contaminação também, porque a sociologia te faz pensar na coisa o tempo todo, é da natureza da disciplina você se interrogar sobre a natureza do fato social e não aceitá-lo puro e simplesmente, e também, perguntar como é que você pode conhecer aquilo também faz parte da sociologia. A sociologia, uma disciplina muito recente e o epicentro da modernidade naquilo que diz respeito à construção da reflexividade, e aí você é contaminado por aquilo, vira um viciado naquilo, absolutamente, e aí você diz: Por que a coisa é assim ? O que está por trás deste atraso? Você torna-se um curioso da vida em sociedade, tem uma vontade de 
entender porque. Chegou num ponto que eu tive que tomar homeopatia porque eu não parava de fazer isso o tempo todo e eu virei uma viciada nessa coisa de interrogar, aí é complicado porque você tem que lidar com a coisa do diário, sem ficar questionando tudo o tempo todo e por outro lado tem que treinar a capacidade de questionar, de desnaturalizar a vida em sociedade; você desnaturaliza a sociedade ao mesmo tempo que você tem que viver com um certo grau de naturalização porque senão é insuportável. Aí como é que você equilibra essas duas coisas? Desnaturalizar e aceitar um certo grau de naturalização, porque senão nem a família te sustenta, é impossível, as redes de amigos, nada disso, porque você começa a questionar o porque isso, porque não tem aquilo, então essa coisa da sociologia ela é muito boa pra quem é curioso e eu sou muito curiosa, e teimoso também por conta da circunstância. Curiosidade junto com teimosia, e um objeto bem curioso também e complexo, em que você junta os pedaços e vai montando, isso é muito fascinante para quem gosta. Como socióloga, e sobretudo porque não queriam que existissem muitos sociólogos, não dava pra ser mais ou menos, porque ou você ia à luta de uma vez e segurava qualquer coisa, ou não ia e não tinha jeito mesmo. Era um tipo de jogo e isso era muito realidade do período, mas é muito gostoso também, você pensa, o domínio do pensamento que você vai adquirindo aos pouquinhos e o que isso é em termos de liberdade individual e também de proteção da mente em momentos adversos. É muito bom pra você proteger sua mente, você começa, por isso que até hoje eu acho muita graça e até rio muito, então tem o lado lúdico que também é muito atraente.

Geosul - Ouvindo a sua trajetória queríamos compreender os encontros com outras disciplinas, e aí eu penso na geografia, como uma socióloga encontra a geografia e os geógrafos e também os movimentos sociais; estaria já numa fase de alguém que está formada?

Ana Clara - Eu nunca me acho formada de jeito nenhum. Para mim é outro lado que eu também acho muito engraçado, eu acho 
que estou começando sempre e não sou formada para nada, e isso tem um aspecto bom porque você continua achando que não sabe grande coisa e tem muito que aprender, e isso é muito legal também pois movimenta o espírito. Como socióloga foi o seguinte, tive dois nãos para a entrada no mestrado e foi difícil quando os nãos vieram, mas depois aprendi uma grande lição, que passo para pessoas que vivem a mesma experiência. Eu digo assim, só merece um sim quem agüenta um não, porque você tem que superar alguma coisa, e quem sabe amadurecer e merecer um sim. No meu caso as razões não foram legítimas para os nãos. Isso foi na Universidade em São Paulo, pois eu tinha uma enorme esperança de fazer o mestrado em São Paulo, apesar de ser muito difícil pra mim pragmaticamente, mas era o lugar mais livre, ainda, apesar da repressão, era mais livre pra você pensar porque no Rio o massacre foi maior ainda do que em São Paulo. Eu queria muito fazer o mestrado em São Paulo e levei lá o meu projeto, não vou dizer para quem, porque na época havia seleção por professor orientador, e aí foi terrível porque eu conhecia muito bem o sul de São Paulo por conta de relações familiares de Francisco, meu marido. Era sobre a formação da estrutura agrária, sobretudo a formação de um assalariado em que você retirava os sitiantes e criava aquilo que depois se chamou de bóia-fria. Foi um estudo que fiz pra essa região sobre a transformação na relação de trabalho e a pessoa disse que aqueles fenômenos não estavam acontecendo porque afinal de contas ela pesquisava o estado de São Paulo. Mas estudava o Vale do Paraíba! O que é que eu tenho a ver com o Vale do Paraíba se estava estudando sobre o sul de São Paulo onde efetivamente essas coisas estavam acontecendo. Quando eu comecei a questionar, a pessoa disse: Olha Ana Clara, os meus bolsistas estão lá fora! Eu digo: Obrigada. Levantei e saí, voltei para o Rio de ônibus, sabendo exatamente onde o meu pé não voltaria. O outro não foi outra comedia de abuso vamos dizer, porque fiz um ano de arqueologia e era bolsista do setor de arqueologia do Museu Nacional, com uma grande arqueóloga e classificava "grifiliticos". Adorava fazer isto e aí fui tentar fazer 
um mestrado de antropologia, e brincando na secretaria, disse que não sabia se queria fazer Arqueologia ou Antropologia. A secretária ouviu e foi falar com a comissão de seleção, e isso eu soube depois por uma colega minha que já era professora. Depois me chamaram, dizendo que foi um erro, mas aí tenho essa coisa, além de teimosa eu sou orgulhosa também, e eu disse, então, mas agora quem não quer sou eu. $\mathrm{Na}$ verdade eu já tinha passado pro IUPERJ $^{6}$ pra sociologia, o que eu fiz foi estudar antropologia durante o verão inteiro pra saber exatamente o que eu queria, e eu descobri que eu queria era ser socióloga mesmo. Então eu fui fazer o mestrado que foi muito bom mesmo e muito importante pra mim. Fiz um curso bem consistente, um mestrado de quatro anos. Muito formador, mas a vida é muito das oportunidades que aparecem também. Tive vários episódios de demissão, eu mesmo pedi demissão da universidade porque não dava para continuar, tive outros episódios de demissão, como do IBRADES, trabalhei tempos lá, mas nós tínhamos, eu e uma amiga, a prática de usar como mão de obra, para a apuração de pesquisa e tudo mais, dados de pesquisas e coordenadas, e nós usávamos essa mão de obra inclusive para dar dinheiro, e aí nossa situação foi ficando muito ruim dentro da instituição, acabamos demitidas. Depois fomos para a Fundação Oswaldo Cruz, onde coordenamos uma pesquisa no programa do Sérgio Arouca sobre campanhas sanitárias, e aí também foi um episódio muito ruim que foi a demissão e também a ficha no $\mathrm{SNI}^{7}$. Eu estava grávida do meu terceiro filho, uma situação sem dinheiro e muito ruim, aí que Helena Lewin, essa pessoa absolutamente genial, foi na maternidade e falou: você topa? (trabalho) Então diversas vezes a Helena esteve na minha trajetória me salvando assim, me levou, por exemplo, para fazer a especialização em demografia que foi forte e me ajudou a sobreviver nos anos 70. Avançando nesse percurso durante os anos 70, buscando uma oportunidade de trabalho, me convidaram, não me lembro exatamente quem, pra dar aula de sociologia urbana no

\footnotetext{
${ }^{6}$ Instituto Universitário de Pesquisa do Estado do Rio de Janeiro.

${ }^{7}$ Serviço Nacional de Informação.
} 
mestrado de Geografia. Então eu fui professora de muita gente no mestrado na UFRJ. Era um contrato, eu não podia ficar fixa, me pagavam com recurso de pesquisa. Dei 10 anos de sociologia urbana na Geografia, no mestrado de geografia, o Marcelo Lopes de Souza foi meu aluno, o Ruy Moreira também, o Carlos Valter, essa turma toda que se formou ali nessa época. Eu tive a oportunidade de conhecer o Marcelo Lopes, são muito carinhosos comigo por conta dessa experiência durante esse período. Isso antes de conhecer Milton Santos, eu já tinha essa interação com a Geografia, só que eram interações que eram analisadas pela sociologia urbana, e não tinha vontade de aprender nada de espaço coisa nenhuma. A aula de sociologia urbana pressupõe você entrar na área de movimentos sociais, porque não tem como você trabalhar com a sociologia urbana sem tentar entender como é que os conflitos acontecem, como é que as reivindicações acontecem, como é que a transformação da sociedade acontece, e a área de sociologia urbana era muito politizada na América Latina; se trata a marginalidade social, as teorias da marginalidade da dependência, então tudo isso tem uma face política em ciências sociais, e isso eu passava porque era da disciplina da sociologia urbana nos 70 e as aulas incluíam essa parte, e não tinha como não trabalhar porque você tratava da marginalidade, daí entrava também toda a parte de lutas sociais que correspondem à tentativa de superação da própria marginalidade, então isso faz parte do constructo da área de sociologia urbana. Só fui conhecer Milton Santos em 78, a partir desse contato, curiosa experiência aleatória, não sei como isso foi acontecer, foi uma coisa maluca, porque também não era para acontecer e aconteceu, minha vida é cheia de acasos, então conheci o Milton, e a partir de Milton é que a questão do espaço como questão começou a entrar em mim, porque até então eu tinha a questão social, mas não tinha a questão do espaço. $\mathrm{Na}$ interação com Milton que é uma beleza de interação, eu fui introduzida à dimensão do espaço que é uma dimensão plena, mas custou muito para mim. Eu pensava "Meu Deus o que esse povo tá dizendo", ficava olhando assim "mas o que as pessoas tão dizendo 
pra mim" quando destacam a dimensão do espaço, não é uma coisa natural para um sociólogo de maneira nenhuma, é muito estranho que você fique destacando a questão do espaço, é muito estranho, e que determina uma coisa a partir daí, como uma instância. Isso ainda é pra mim uma coisa muito complicada, mas na época era estarrecedor porque eu estava vendo as relações sociais que se traduzem em espaço, então a coisa foi indo e aprofundando a nossa relação de pesquisa. Vai crescendo também porque a minha situação na universidade se tornou mais esperançosa. No início dos anos 80 já apareceu uma outra oportunidade de interação, aos pouquinhos a coisa foi melhorando, eu como professora visitante. Eu trabalhei com a área da saúde, então tem uma série de entradas que fazem com que eu como socióloga tenha ficado fechada na sociologia sim, nos sociólogos não, então quer dizer eu nunca tive a pretensão de ter um grande papel na sociologia, ou fazer a carreira apenas no campo da sociologia, mas a riqueza do pensamento e o direito de pensar isso sim, então eu me vejo como uma socióloga mesmo, eu sou uma socióloga, mas não fechada no campo da sociologia. Eu gosto muito de interagir com outras áreas, e atualmente as áreas são a geografia e a arquitetura e urbanismo, mas através da mediação da cultura.

Geosul - Enfim, tem essas interações que se dão nas relações de trabalho, com Milton Santos e muitos outros. Ao mesmo tempo você tem um papel muito importante como formadora de quadros e eu sei que lá no IPPUR $^{8}$ você recebe estagiários de muitas áreas, inclusive muitos da Geografia. Como é essa experiência de uma socióloga que recebe estudantes formados em outros campos?

Ana Clara - Isso é ótimo. A pergunta que você faz, por causa da episteme, quer dizer como na verdade essa formação de sociologia, que eu tive a sorte de ter boa, colocou sempre que a sociologia era uma concretização, era uma concreção possível histórica de algo maior, que é o conhecimento. Você tem então uma noção

${ }^{8}$ Instituto de Pesquisa e Pós-Graduação em Planejamento Urbano e Regional da UFRJ. 
construída da filosofia, da teoria da epistemologia, e aí sim a sociologia, mas não a sociologia trancada dentro dela mesma, você tem uma abertura do espírito para as outras ciências, e não fica só na sociologia. Isso eu acho que me protegeu muito quando eu fui dar aula no IPPUR e os meus orientandos vinham muito da arquitetura e urbanismo, da engenharia; não tinha nenhum sociólogo. Para mim era uma coisa muito complexa entender a cabeça deles, porque eu acho que a gente tem que entender a cabeça do outro, se não você não pode orientar. Já pra mim foi muito complicado dar aula de demografia para economistas, que eu dei muitos anos, oito horas de aula semanais, e era uma coisa complicadíssima porque eles não entendiam meu código linguístico e eu também não entendia o deles. Então era uma coisa, uma "complicação complicadíssima", e depois com a orientação fiquei mais apavorada ainda, quando eu descobri que não teria nenhum aporte superior, porque eu pensava que para você orientar alguém, você deveria ter um orientador, tinha que ter um negócio desses para você eventualmente fazer uma consulta. Isso é uma loucura. Enfim, aí fui acompanhando a cabeça das criaturas e eram cabeças completamente diferentes da minha, elas armavam diferente o raciocínio, tive que descobrir uma chave de acesso aos arquitetos, eles tem que fazer um diagrama lógico, se eles não produzirem o diagrama, eles não andam e ficam incertos, ansiosos, nervosos e tristes. Então aos poucos eu fui entendendo qual era a razão lógica que estava por trás daquela base de reflexão, como é que aconteciam as causalidades, as determinações, os fatores estruturais do pensamento, para de tal forma poder armar um diálogo, até para as pessoas não entrarem no campo das ciências sociais incertas. Como você vai trazer a incerteza para dentro da certeza? Isso é uma coisa muito séria. Então com essa experiência eu fui aprendendo a construir os diálogos diferenciados. Lá os meus geógrafos e sociólogos não têm muito prejuízo, por conta do acúmulo de relacionamento que eu já tenho com a geografia, então é de uma maneira intensa como a cabeça deles está armada, não que eu saiba totalmente o conteúdo da teoria da geografia, afinal de 
contas eu não sou geógrafa, mas eu posso entender a natureza das questões deles, porque são aquelas, qual é a gênese? Aí de alguma forma nós interagimos sobre os objetos empíricos e os desafios do real, então eles trazem a contribuição deles, eu trago a nossa, os sociólogos lá do laboratório trazem a deles, e nós fazemos uma interação em cima do real, não com orientação disciplinar antecedendo aquilo que está acontecendo. Como o laboratório é todo baseado na construção empírica, ou seja, nós trabalhamos metodologicamente com a questão social, e a questão social tem tempo e espaço concretamente, então trabalhamos com essas dimensões do real. Novas formas de ação: quem é que está nas ruas, como isso está acontecendo? Por que aquilo acontece naquele lugar lá e no outro não? Portanto cada um traz a sua contribuição, e a gente discute, faz um trabalho de leitura coletiva de textos de várias origens em cima do que a questão pede. Não necessariamente da geografia ou da sociologia, e isso gera uma experiência muito rica. Muitas pessoas se formaram no laboratório, com visões que são muito humanísticas, com leituras que são epistemologicamente abertas, com uma série de contribuições que não são disciplinadas, mas sim, interdisciplinadas, e acima de tudo epistemológicas. Os meus geógrafos são incríveis porque eles veem coisas nas ruas, conhecem coisas que não acabam mais; então eu trago um problema de pesquisa, e eles colaboram muito com a criação dos correspondentes empíricos, e vão trabalhando junto. São muito generosos e muito autônomos, eles vão propondo e a gente vai conversando, é muito agradável mesmo. Eles estão interagindo também com as meninas da arquitetura, na medida em que os eventos vão acontecendo. Tem a Paola Berenstein que é uma intelectual sem dúvida, que germina muito para a área, então nós interagimos muito, e eu participei do "Corpo Cidade" na Bahia, mais a Fabiana da escola de dança da Bahia, e agora o "Corpo Cidade II" vai ser no Rio de Janeiro e Salvador. Tem a Margareth Pereira, e o programa pró-cultura com a Maria Helena da $\mathrm{UFMG}^{9}$. Então tem uma linha de trabalhos fantástica rolando de

${ }^{9}$ Universidade Federal de Minas Gerais. 
meninos da geografia e sociologia com as meninas da arquitetura e urbanismo, e temos a dimensão cultural e das novas formas de ação. Então você propunha não o trabalho, mas uma provocação, e como elas são maravilhosas, elas não definiram o que é uma provocação. Então os meninos da geografia e sociologia, propuseram três provocações que foram aceitas. A primeira provocação é muito curiosa, você vai colocar um colchão ali, rompendo o espaço público e o privado, então o que acontece? Então isso tudo vai ser sinalizado, essa é a ideia. Tem outra ideia que é levar a cartografia da ação para a escola pública da Maré ${ }^{10}$. Tem outra que foi absolutamente inovadora que juntou a menina da geografia, ex-orientanda da Ana Fani Carlos, que está lá comigo como orientanda de mestrado, ela já trabalhou o teatro lá em São Paulo que está bem próximo da nossa área de interesse. A Raquel, que também é ótima, é orientanda de Ana Fani, e o Vinícius que é um menino formado em sociologia que é meu orientando de mestrado também. Eles vão propor a seguinte provocação: eles vão tirar imagens, fotografias de várias origens, vão distribuir no chão, numa roda de pessoas, as pessoas escolhem o que quiserem, e vão relatando a partir do que aquilo provoca nelas e aí vai circulando esse relato, que aparece como narrativa e que possa ser um produto coletivo. Então é muito legal, porque acho que vem da contemporaneidade você não respeitar tão rigorosamente as fronteiras e também de uma interação por fora mesmo, as pessoas vem se encontrando de uma outra maneira. Então trabalhamos juntos de uma forma muito interessante, sem perder o perfil. Tenho estimulado que os geógrafos publiquem na geografia, então foram para a $\mathrm{AGB}^{11}$, para o encontro dos estudantes de geografia, levando os trabalhos feitos por eles no IPPUR, financiados pelo laboratório e, ao mesmo tempo, os sociólogos vão para o encontro de sociólogos. O Vinícius participou de uma oficina para

${ }^{10}$ Complexo da Maré na cidade do Rio de Janeiro congrega diversas favelas no continente no acesso a Ilha do Fundão onde se encontra a Universidade Federal do Rio de Janeiro.

${ }^{11}$ Associação dos Geógrafos Brasileiros. 
professores de sociologia do ensino médio. Eu tento não desenraizar, por conta da questão da interação que se tem, desenraizar completamente os profissionais eu tenho muito medo disso, de você ficar decapitando as pessoas, eu acho isso aí muito preocupante. Para mim a formação primeira, a formação de graduação, é muito marcante e as pessoas não conseguem gerar essa formação completamente.

Geosul - Como é sua relação com a coordenação dos grupos do desenvolvimento urbano?

Ana Clara - A modernização do Brasil, mesmo na ditadura, foi uma modernização muito forte, uma mecanização muito intensa, uma visão de mundo que fortaleceu a Europa, os Estados Unidos, mas você não tinha mais o mesmo ideário político, a mesma problemática compartilhada com os outros países da América latina, não de revolução, mas de desenvolvimento mesmo, de modernização, então isso se perdeu vamos dizer assim, muito a economia abstrata, não a economia de um Celso Furtado evidentemente, mas uma economia abstrata é muito quantitativa em história e geografia, essa economia hegemônica, quantitativa no mau sentido, que de uma maneira se tornou um fator de abstração do próprio território nosso, não é nem uma questão sobre a América latina, é uma descentralização e desenraizamento cultural mesmo, muito forte durante os períodos mais duros do Brasil, mas junto também com o crescimento econômico extremamente agudo nesse período do milagre brasileiro. Isso transforma as leituras, não só de América Latina, dos vínculos internacionais, mas também do próprio Brasil. Tudo isso acontece ao mesmo tempo. Para mim sempre houve uma dívida de geração, eu tinha uma dívida de geração, e a minha dívida de geração era a América Latina, e eu não me conformei com essa perda completamente, vamos dizer assim. Eu sempre usei muito a literatura latino-americana mesmo nessas disciplinas de sociologia urbana, e eu queria muito pagar essa dívida de geração, ou seja, queria resgatar o vínculo cultural nas ciências sociais, da sociologia latino-americana. Aí surgiu um 
convite para formar um núcleo de desenvolvimento urbano. Porque eu tinha um vínculo muito forte com grandes quadros, estudava muito sobre a América Latina, sobre a África, porque ainda éramos herdeiros daquela visão de terceiro mundo. Tinha a guerra do Vietnam, e depois comecei a me interessar sobre os outros países, então tinha que procurar, tinha uma coisa assim de terceiro mundo que ainda rondava nossa geração. Em Recife, quando se formou a Assembléia do Clacso $^{12}$, em 1999, nós fizemos a primeira mesa. Aí a coisa foi sendo consolidada, ganhamos três rodadas de Clacso, são de três em três anos essas seleções, e nós ganhamos. Só que eu comecei a ficar muito cansada, porque isso é extremamente cansativo, porque você tem que mobilizar, "tem que multiplicar os pães", porque o dinheiro é pouco, então é hospedagem, organizar a passagem, essa coisa toda, editar os relatórios para fazer os livros, realmente é um esforço muito grande. Nossos grupos entraram no Fórum Social Mundial, em Porto Alegre, e participaram, foi bacana como experiência. Fiz ainda o projeto de nós continuarmos, mas sofremos muita concorrência porque entraram outros grupos do Brasil, porque cresceu muito a vinculação do Brasil ao Clacso, e aí vamos dizer entraram outros concorrentes na área de urbano, e eu não quis coordenar, a coordenação passou para um colega nosso da Bolívia e não foi aprovado. Então agora estamos tentando entrar outra vez com o projeto do grupo, nós tivemos que mudar de nome, e não consegui entrar nessa convocatória. Se nós formos aprovados vamos conseguir resgatar uma parte da rede do Clacso, e a ideia é conseguir resgatar uma parte do dinamismo do grupo; nós éramos todos organizados, por vários países, tínhamos na Bolívia, na Colômbia, no Uruguai, na Argentina. O primeiro encontro foi no Brasil, mas depois os outros países organizaram, como El Salvador, então eu sei que conseguimos resgatar uma parte dessa rede, isso é uma coisa boa, mas pra mim era grande demais, é muito trabalho. Acho que agora está completamente configurada essa interação latino-americana, muito forte, porque os outros países sempre tiveram, nós é que ficávamos para cá, com pouca

${ }^{12}$ Consejo Latinoamericano de Ciências Sociais. 
interação, não só interna como também com eles então, mas entre eles é uma coisa impressionante. A influência da Argentina e do México é enorme, no México boa parte das afiliadas ao Clacso é mexicana, então no México têm um dinamismo gigantesco, uma universidade maravilhosa.

Geosul - Ficamos curiosos verificando que em seu curriculum lattes você destaca como uma das principais publicações o artigo "Cidade e capitalismo periférico em direção à experiência popular", e aí nós queríamos ouvir um pouco sobre como você liga várias coisas: a cidade, a questão da América latina, a questão dos movimentos...

Ana Clara - É, uma coisa assim, isso aí foi publicado, como é que chama? Margem esquerda, e acho que ele é Marxista o texto, finalmente, não aquele marxismo ortodoxo, eu não sou boa para fazer a cabeça de ninguém, faço a criatura entender a cabeça dela e interagir com ela; agora fazer a cabeça dos outros não é da minha natureza, eu não gosto de fazer isso. Eu fico danada quando ficam fazendo isso comigo, agora imagina fazer com os outros. $\mathrm{O}$ Marxismo, pra mim, é a melhor corrente de pensamento para explicar a sociedade, quer dizer não é uma questão apenas ideológica, mas é porque mantém realmente as análises estruturais enriquecidamente construídas pela história da humanidade, também pelas mediações entre cultura e matéria da forma mais plena possível. Então quer dizer, a totalidade do marxismo é uma coisa extraordinária, que você pode ver ao longo do século $\mathrm{XX}$, a quantidade de correntes marxistas que surgem, inclusive a do Lefèbvre, e por aí vai, quer dizer, nós temos uma quantidade imensa de correntes. Meu perfil político é muito complexo, também pela estabilidade das coisas é muito fácil você rotular uns que foram vítimas da ditadura, mas quem não foi exatamente isso, apesar de ter sido, não formal, mas visivelmente colocado, é muito difícil você se colocar, e deixar você em paz para dizer o que bem entende, inclusive a partir do marxismo. Então eu adorei essa oportunidade, estão me convidando, eu vou fazer o que eu quero. 
Fiquei muito honrada com essa possibilidade e tentei juntar os resgates então, todos eles ao mesmo tempo, do marxismo, da América Latina, tudo junto. E por isso que ele é, para mim, particularmente importante, porque também tem uma referência histórica do pensamento sociológico latino-americano, a importância da tradição do pensamento social latino-americano, do pensamento crítico e da questão da marginalidade que também está dentro do marxismo latino-americano. Eu tentei fazer o resgate de várias coisas para separar minhas dívidas, que são dívidas espirituais, são minhas, então achei formidável poder publicar nesta revista, não ter sofrido qualquer tipo de rótulo, nem exigência prévia, me deixaram feliz de poder escrever o que eu queria, e aí realmente eu fiquei muito honrada, e aí escrevi esse artigo que pra mim é importante, não por ele mesmo, porque não tive nem cabeça para dizer o que era mais importante, o que era menos importante, sei lá o que é e o que não é, talvez esse não seja um dos mais elaborados, mas tem sentido para mim. Tem um sentido maior do que muitas outras coisas, por conta dessas referências não ditas no caso, mas é importante que seja no marxismo, que seja nas revistas, na América Latina.

Geosul - Como é que a senhora vê o Brasil hoje do ponto de vista da sociologia, dos movimentos, do que está acontecendo?

Ana Clara - Pois é! Estive num encontro da Associação Nacional dos Direitos Humanos em Brasília há pouco tempo, participei de um debate na UFRJ sobre o Brasil que queremos nos próximos quatro anos, mas no momento eu não sou portadora de boas notícias, eu não tenho nada a ver com o marketing, até porque eu não faço a cabeça de ninguém. Muitas vezes isso é desagradável, porque você poderia ser portadora de esperança, de coisas boas, e eu não consigo ver isso. A sociedade brasileira é muito cruel, é muito desigual, e aí eu estava lendo agora Francisco de Oliveira, aquela publicação "O Brasil que queremos", também desse centro do Celso Furtado, e eu comungo muito com aquilo que o Francisco de Oliveira está dizendo. O Brasil é e está profundamente desigual, 
quando se diz que reduziu a diferença, e aí o Francisco de Oliveira chama a atenção, não está incluindo aí a riqueza, está incluído apenas a diferença salarial em ganho imediato, e de capital você não sabe nada. Quer dizer, o que você vê, o que me assusta é uma desigualdade brutal, descontrole sobre o território, uma privatização do território, por outro lado uma transnacionalização do território que vai ser muito difícil ser controlada, um aumento extraordinário da violência nas relações inter-individuais. Ficam falando que eu sou a pessoa dos evangélicos, aquela coisa reacionária. Eu digo é reacionário também avaliar reacionariamente os evangélicos, não compreendê-los. Vejo ali o retorno aos valores tradicionais na orientação dos filhos, porque o avanço da modernização sem estruturação é de altíssimo risco para os indivíduos, então é uma coisa complicada. Para a minha geração os princípios da liberdade eram absolutamente orientadores, eu nem orientei meus filhos desse jeito. Mas de qualquer forma é muito complicado você imaginar para famílias em situação de insegurança social, vulnerabilidade extrema, imaginar ou exigir delas que sejam progressistas, culturalmente, soltas. Dificílimo é não termos uma alternativa, então muitas vezes as "seitas" evangélicas sustentam bem ou mal a sociabilidade da juventude, atuam em presídios, atuam onde as outras forças sociais não entram. Quer dizer, não é uma gratuidade. Acho que temos que entender um pouco a difícil equação que estamos vivendo, de um lado o mercado absolutamente efervescente que propõe de toda a forma o individualismo, que esqueça o seu entorno e vá em frente, então esse lado da competitividade muito forte, não chega nem a ser consumismo eu acho, é o desejo de toda a ordem. Então você tem isso muito saliente e ao mesmo tempo, vamos dizer, uma falta de sustento, sustento cotidiano, sustento da existência, aquelas garantias básicas. Esse deslocamento de uma coisa e outra é muito violento, e gera violência e dá em qualquer coisa que você não sabe o que é. Sociologicamente é extremamente preocupante e eu chamo de "Crise Societária", que não é crise social, é crise societária da totalidade social, da sociedade brasileira como um 
todo. Então ele tá, vamos dizer assim, crescendo e reduzindo ao mesmo tempo, se tornando mais volátil e ampliando. Crescendo na sua dimensão de influência, mas não na densidade dos vínculos sociais o que é muito preocupante. Muito preocupante para um futuro próximo da sociedade brasileira, e eu não acho que está se modernizando culturalmente de qualquer forma, sem nenhuma garantia dos indivíduos, das famílias. Acho que a sociedade brasileira tem um tremendo desafio a enfrentar, é claro. Temos de imaginar quais são os sujeitos que estão de fato interessados em enfrentar esse tipo de equação. Certamente não são os do mercado, muitas vezes as formas de governo também não, então é um lado que é do tecido da sociedade, que pode garantir o enriquecimento do próprio tecido da sociedade. Melhorarmos os tecidos sociais, que estão muito desgastados e ao mesmo tempo tentar enriquecer a esfera pública, ou seja, com questões novas, trazendo mesmo para o debate. Existe um movimento que se chama "carta pública", que reune uma série de pessoas amigas, confiantes entre si, numa praça lá em Buenos Aires. Eles se posicionam com relação aos problemas que estão acontecendo, debatem e depois tornam público. Isso vai alargando a esfera pública, o espaço público, vamos dizer assim. Então eu creio que isso é necessário como estratégia: alargar o espaço público, a esfera pública e a densificação dos vínculos sociais. Porque se não apresentarmos alternativas, não temos o porquê de ficar jogando pedra em quem faz. Acho que é um momento bem monstruoso, porque nós somos o continente mais desigual do mundo, e o Brasil é o mais desigual de todos, então quer dizer, nós temos uma situação terrível social, muito ruim, enfeitada como se enfeita bolo, soltando fumaça que nos impede de ver a nossa sociedade terrível, e com avanços e recuos. Temos alguns avanços também, mas dizer que a coisa está boa e garantida, de jeito nenhum. Então a leitura é bem essa mesmo, de valores.

Geosul - Agradecemos a sua disposição para a entrevista! 